\title{
PERPPU, BUKAN SOLUSI AKHIR PEMBUBARAN ORMAS Tinjauan Politik dan Hukum
}

\author{
Anak Agung Ngurah Agung Wira Bima Wikrama
}

Program Studi Ilmu Administrasi Negara

Fakultas Ilmu Sosial dan Ilmu Politik, Universitas Mahendradatta

Jl. Ken Arok No. 12, Peguyangan Denpasar

E-mail:bimawikrama65.gmail.com

\begin{abstract}
Abstrak - Organisasi kemasyarakatan yang terbentuk di Indonesia memiliki tujuan yang berbeda-beda sesuai dengan keinginan kelompok yang membentuknya. Dari sekian banyak organisasi tersebut, terdapat pula organisasi yang dibentuk untuk tujuan meraih kekuasaan. Terdapatnya organisasi kemasyarakatan radikal yang sering melakukan kegiatan anarkis di Indonesia telah membuat pemerintah Indonesia harus melakukan pengendalian berupa pembatasan-pembatasan, mulai dari pengendalian ijin kegiatan, tempat kegiatan, seperti yang diatur dalam UU No.17/2013 tentang organisasi kemasyarakatan. UU No.17/2013 tersebut ternyata belum mampu untuk mengatur keberadaan organisasi kemasyarakatan secara komprehensif hingga keluarlah Peraturan Pemerintah Pengganti Undang-Undang nomor 2/2017 tentang Perubahan atas UU Nomor 17/2013. Pembatasan yang sudah dilakukan, sering kali tidak efektif untuk mengendalikan organisasi kemasyarakatan karena tidak diimbangi oleh tindakan tegas berupa pembubaran. Pembubaran yang dimaksud dalam Undang-Undang tentang ormas pun tidak serta merta dapat membubarkan ideologi organisasi kemasyarakatan tersebut sehingga gerakan organisasi tanpa nama atau tanpa bentuk (OTB) pun menjadi pilihannya dan mereka selalu berlindung di bawah Undang Undang Dasar 1945 pasal 28E ayat 3 yang menyatakan setiap orang berhak atas kebebasan berserikat, berkumpul dan mengeluarkan pendapat. Klausul inilah yang menyulitkan pemerintah dalam membubarkan organisasi kemasyarakatan yang berbahaya bagi bangsa dan negara. Sehingga solusi yang penulis tawarkan dalam mengatur keberadaan organisasi kemasyarakatan di Indonesia adalah melakukan amandemen UUD 1945 dengan menambahkan kewenangan pada lembaga Mahkamah Konstitusi (MK) yang bukan saja diberikan untuk membubarkan Partai Politik tetapi diberikan pula kewenangan untuk membubarkan organisasi kemasyarakatan yang berbahaya bagi kelangsungan kehidupan berbangsa dan bernegara.
\end{abstract}

Kata Kunci: Perppu, Pembubaran, Organisasi Kemasyarakatan.

\section{PENDAHULUAN}

\section{Latar Belakang}

Sistem hukum yang berlaku di Indonesia mengamanatkan bahwa seluruh peraturan dan perundang-undangan di Indonesia harus bersumber dan mengacu pada Pancasila dan Undang-Undang Dasar 1945. Dalam perkembangan selanjutnya, DPR bersama pemerintah diberi ruang untuk membuat peraturan turunan yang berbentuk Undang-Undang. Dalam pembentukannya, seluruh pikiran harus selaras dengan Undang-Undang Dasar
1945 sehingga tidak ada satupun Undang-Undang yang dihasilkan oleh DPR bersama pemerintah bertentangan dengan Undang-Undang Dasar 1945.

Dalam Undang-Undang dasar 1945 (Amandemen) Pasal 28E ayat (3) UUD 1945 dinyatakan bahwa, "Setiap orang berhak atas kebebasan berserikat, berkumpul, dan mengeluarkan pendapat". Hal tersebut merupakan sebuah cerminan bahwa Indonesia merupakan sebuah negara yang menerapkan prinsip-prinsip demokrasi. Walaupun demikian hak untuk berserikat, berkumpul dan mengeluarkan pendapat harus didasarkan pada tanggung 
jawab dengan tidak merugikan orang lain atau kelompok lain yang lebih luas.

Pembentukan organisasi kemasyarakatan merupakan bentuk kebebasan berserikat yang dilindungi oleh Undang-Undang Dasar 1945. Selanjutnya pendirian organisasi kemasyarakatan diatur melalui Undang-Undang Republik Indonesia Nomor 17 tahun 2013 tentang Organisasi Kemasyarakatan. Dalam Undang-Undang tersebut dimuat secara rinci tentang pembentukan sebuah organisasi kemasyarakatan, kiprahnya dalam masyarakat dan bila terdapat pelanggaran maka terdapat sangsi yang akan diterima organisasi kemasyarakatan tersebut. Tetapi kenyataannya tidak ditemukan sangsi yang tegas bekaitan dengan pembubaran sebuah organisasi kemasyarakatan.

Kenyataan tersebut akan dibahas penulis dalam tinjauan Politik dan Hukum sehingga lebih mudah dianalisa dan dipahami. Penulis akan menguraikan permasalahan yang mendasari dan factor-faktor yang mempengaruhi sehingga ditemukan penyebab dari berlarutnya pembubaran organisasi kemasyarakatan yang dianggap bermasalah di Indonesia. Penulisan buku ini diberi judul "Jalan Panjang Pembubaran Organisasi Kemasyarakatan di Indonesia”.

\section{Landasan Teori}

\subsection{Teori Relasi Kekuasaan}

Pembicaraan mengenai kekuasaan merupakan satu hal menarik yang tidak pernah selesai dibahas. Hal ini telah dimulai sejak jaman Yunani kuno dan terus berlangsung sampai saat ini. Para filsuf klasik pada umumnya mengaitkan kekuasaan dengan kebaikan, kebajikan, keadilan dan kebebasan. Para pemikir religius menghubungkan kekuasan itu dengan Tuhan. Kekuasaan politik hanya sebagai alat untuk mengabdi tujuan negara yang dianggap agung dan mulia, yaitu kebaikan, kebajikan, keadilan, kebebasan yang berlandaskan kehendak Tuhan dan untuk kemuliaan Tuhan.

Beberapa dekade yang lalu Michel Foucault, salah seorang filsuf pelopor strukturalisme juga berbicara tentang kekuasaan. Konsep Kekusasan Foucault dipengaruhi oleh Nietzsche. Foucault yang menilai bahwa filsafat politik tradisional selalu berorientasi pada soal legitimasi.
Kekuasaan adalah sesuatu yang dilegitimasikan secara metafisis kepada negara yang memungkinkan negara dapat mewajibkan semua orang untuk mematuhinya. Namun menurut Foucault, kekuasaan adalah satu dimensi dari relasi. Di mana ada relasi, di sana ada kekuasaan.

Dalam hal ini, penulis mencoba menguraikan konsep kekuasaan Michel Foucault berdasarkan beberapa karya utama yang ia tulis semasa hidupnya. Kekuasaan menurut Foucault ada di mana-mana. Hal pertama yang akan dibahas di sini yaitu tentang hubungan antara kekuasaan dan diskursus ilmu pengetahuan. Menurut Foucault kehendak untuk kebenaran sama dengan kehendak untuk berkuasa. Dalam Kegilaan dan Peradaban, Foucault melukiskan bagaimana kegilaan itu didefinisikan dari berbagai kelompok yang dominan pada masa tertentu. Karena itu dia meragukan legitimasi eliminasi kegilaan dari kebudayaan yang resmi.

\subsubsection{Latar Belakang Pemikiran Michel Foucault}

Foucault adalah seorang yang skeptis terhadap segala macam kebenaran. Baginya segala macam klaim kebenaran adalah interpretasi atas sebuah dunia, yang sebenarnya tidak ada sebagai sesuatu yang historis. Untuk itu dia menyelidiki cara berpikir dan sejarah peradaban. Misalnya dalam Kegilaan dan Peradaban dia melukiskan bagaimana kegilaan itu didefinisikan dari berbagai kelompok yang dominan pada masa tertentu. Di sini Foucault menguraikan bahwa pandangan dan cara pengobatan seorang dokter sungguh sangat dipengaruhi oleh berbagai kondisi pengetahuan, institusional, pedagogis, keamanan dan seterusnya.

Hampir dalam seluruh uraiannya tentang kekuasaan, Foucault menggunakan gagasan dari orang lain sebagai bahan, tetapi selalu diolah dan dimasukkan secara inovatif ke dalam bangunan konsepnya sendiri. Sebab itu kita dapat menemukan konsep Nietzsche di sana. Dia menjadikan uraian Nietzsche tentang kekuasaan sebagai basis refleksi kebudayaan dan filosofisnya. Filsafat politik tradisional selalu berorientasi pada soal legitimasi. Kekuasaan adalah sesuatu yang dilegitimasikan secara metafisis kepada negara yang memungkinkan negara dapat mewajibkan 
semua orang untuk mematuhinya. Namun menurut Foucault, kekuasaan bukanlah sesuatu yang hanya dikuasai oleh negara, sesuatu yang dapat diukur. Kekuasaan ada di mana-mana, karena kekuasaan adalah satu dimensi dari relasi. Di mana ada relasi, di sana ada kekuasaan.

Kuasa itu ada di mana-mana dan muncul dari relasi-relasi antara pelbagai kekuatan, terjadi secara mutlak dan tidak tergantung dari kesadaran manusia. Kekuasaan hanyalah sebuah strategi. Strategi ini berlangsung di mana-mana dan di sana terdapat sistem, aturan, susunan dan regulasi. Kekuasaan ini tidak datang dari luar, melainkan kekuasaan menentukan susunan, aturan dan hubungan-hubungan dari dalam dan memungkinkan semuanya terjadi.

\subsubsection{Konsep Kekuasaan Michel Fou- cault}

Seperti telah diuraikan di atas, konsep kekuasaan Foucault sebenarnya banyak dipengaruhi oleh Nietzsche. Ia melihat ada kesamaan pikiran Nietzsche tentang genealogi dengan pikirannya tentang arkeologi tapi ada unsur dalam genealogi Nietzsche yang belum nampak yaitu kuasa. Selanjutnya akan dipaparkan beberapa pandangan Foucault tentang kekuasaan berdasarkan beberapa karyanya.

\subsubsection{Kekuasaan dan Ilmu Pengetahuan}

Dalam karyanya The Order of Things, Archeology of Human Sciences, Foucault menunjukkan bahwa ada dua perubahan besar yang terjadi dalam bentuk umum pemikiran dan teorinya. Yang pertama terjadi pada pertengahan abad ke-17, yang kedua pada awal abad ke-19. Setelah menganalisis diskursus ilmu pengetahuan abad ke-17 dan 18 seputar sejarah alam, teori uang dan nilai, dan tata bahasa, Foucault mengambil kesimpulan bahwa pusat ilmu pengetahuan pada waktu ini adalah tabel. Orang hendak merepresentasikan realitas dalam tabel. Tabel adalah satu sistem tanda, satu bentuk taksonomi umum dan sistematis dari benda-benda. Dengan konsentrasi pada tabel, pengetahuan pada masa ini menjadi ahistoris.

Pada akhir abad ke-18 (setelah revolusi Prancis) sampai pertengahan abad ke-20 (Perang Dunia II), konsentrasi wacana ilmiah pada masa ini adalah sejarah dan manusia sebagai subjeknya. Manusia dibebaskan dari segala alienasi dan bebas dari determinasi dari segala sesuatu. Manusia menjadi objek pengetahuan dan dengan demikian dia menjadi subjek dari kebebasan dan eksistensinya sendiri. Manusia menjadi pusat pemikiran. Hal ini terlihat dalam perkembangan ilmu-ilmu sosial dan psikologi.

Objek penelitian Foucault dalam karya ini adalah kondisi-kondisi dasar yang menyebabkan lahirnya satu diskursus. Di sini Foucault menunjukkan hubungan antara diskursus ilmu pengetahuan dengan kekuasaan. Diskursus ilmu pengetahuan yang hendak menemukan yang benar dan yang palsu pada dasarnya dimotori oleh kehendak untuk berkuasa. Ilmu pengetahuan dilaksanakan untuk menetapkan apa yang benar dan mengeliminasi apa yang dipandang palsu.

Di sini menjadi jelas bahwa kehendak untuk kebenaran adalah ungkapan dari kehendak untuk berkuasa. Tidak mungkin pengetahuan itu netral dan murni.

Di sini selalu terjadi korelasi yaitu pengetahuan mengandung kuasa seperti juga kuasa mengandung pengetahuan. Penjelasan ilmiah yang satu berusaha menguasai dengan menyingkirkan penjelasan ilmu yang lain. Selain itu, ilmu pengetahuan yang terwujud dalam teknologi gampang digunakan untuk memaksakan sesuatu kepada masyarakat. Karena dalam zaman teknologi tinggi pun sebenarnya tetap ada pemaksanaan, maka kita tidak dapat berbicara tentang kemajuan peradaban. Yang terjadi hanyalah pergeseran instrumen yang dipakai untuk memaksa.

\subsubsection{Kegilaan dan Peradaban}

Foucault melihat praktek pengkaplingan yang memisah-misahkan orang-orang yang sakit dari orang sehat, yang normal dari yang tidak normal merupakan salah satu bentuk aplikasi kekuasaan seseorang atau satu kelompok orang atas yang lain. Foucault menemukan bahwa pada zaman Renaissance, kegilaan dan penalaran memiliki relasi yang erat, keduanya tidak terpisah, sebab keduanya menggunakan bahasa yang sama. Masyarakat tampaknya tidak menolak gagasan-gagasan dan tindakan-tindakan brilian yang lahir dari orangorang yang dicap gila. Kegilaan adalah kebebasan imaginasi, dan masih menjadi bagian dari kehidupan masyarakat dalam 
zaman renaissance.

Namun pada zaman setelahnya (1650-1800), dialog antara kegilaan dan penalaran mengalami pembungkaman. Keduanya dilaksanakan dalam bahasa yang berbeda, dan akhirnya bermuara pada penaklukan kegilaan oleh penalaran, perlahan kegilaan menjadi sesuatu yang asing dan disingkirkan dari kehidupan yang harus dijiwai kelogisan. Bersamaan dengan itu, kegilaan harus disingkirkan dari masyarakat yang normal. Kegilaan telah menjadi satu tema yang membuat masyarakat terpisah dan terpecah.

Apa yang terjadi dengan orang gila, berjalan beriringan dengan apa yang terjadi dengan para penjahat, orang-orang miskin dan gelandangan. Mereka semua mulai disingkirkan, dalam bentuk penjara, rumah sakit umum, rumah sakit jiwa dan ditertibkan oleh sosok polisi dan pengadilan. Semua lembaga ini adalah bentuk yang digunakan oleh penguasa untuk menerapkan kekuasaannya atas masyarakat. Pengangguran adalah satu persoalan sosial, demikian juga semua yang menjadi alasan pengangguran, seperti kegilaan atau sakit. Orang gila dikaitkan dengan orang miskin dan penganggur. Dengan ini, etika menjadi persoalan negara. Negara dibenarkan menerapkan hukuman atas pelanggaran moral. Hukuman mati yang dipertontonkan adalah satu bukti cara pandang seperti ini. Dengan ini sekaligus hendak ditunjukkan bahwa ada kekuasaan. Eksekusi adalah tontonan yang luar biasa dan bentuk pemakluman yang paling efektif dari adanya kekuasaan yang mengontrol.

Dengan demikian, kita dapat melihat inti dari teori Foucault di sini menunjukkan bahwa sakit mental hanya muncul sebagai sakit mental dalam satu kebudayaan yang mendefinisikannya sebagai demikian. Karena menyangkut definisi, maka di dalam sakit mental sebenarnya kekuasaan mendominasi. Kegilaan adalah yang berbeda dari yang biasa, dan karena yang biasa dicirikan oleh produktivitas, maka kegilaan adalah tidak adanya produktivitas. Penanganan kegilaan adalah satu bentuk aplikasi kekuasaan seseorang atau satu kelompok orang atas yang lain, bukan pertama-tama masalah pengetahuan psikologis.

\subsubsection{Disiplin dan Hukuman}

Pada abad ke-17 dan 18, disiplin adalah sarana untuk mendidik tubuh. Praktik disiplin diharapkan melahirkan tubuh-tubuh yang patuh. Hal ini tidak hanya terjadi di penjara, tetapi juga dalam bidang pendidikan, tempat kerja, militer dan sebagainya Masyarakat selanjutnya berkembang menurut disiplin militer. Foucault beranggapan bahwa di era monarkial tiap proses penghukuman kriminal baru dianggap serius apabila telah melibatkan elemen penyikasaan tubuh dalam pelaksanaannya.

Pelaksanaan disiplin amat berhubungan dengan kuasa yang mengontrol. Foucault menguraikan bahwa fenomena disiplin tubuh selalu dikontrol oleh dua instrumen disiplin yang diterapkan dari disiplin militer dalam masyarakat. Pertama, melalui observasi hirarkis atau kemampuan aparatus untuk mengawasi semua yang berada di bawahnya dengan satu kriteria tunggal. Panopticon yang terungkap dalam menara sebagai pusat penjara adalah bentuk fisik dari instrumen ini. Dengan adanya panopticon ini kekuasaan sipir menjadi sangat besar sebab para tawanan berusaha menahan diri mereka sendiri. Mereka takut dipantau. Kehadiran struktur itu sendiri sudah merupakan satu mekanisme kekuasaan dan disiplin yang luar biasa.

Instrumen kedua adalah menormalkan penilaian moral dan menghukum para pelanggar moral. Dalam hal ini kekurangan disamakan dengan kejahatan. Selain dipenjarakan, orang-orang yang menyimpang dipertontonkan. Maksudnya adalah menunjukkan kepada masyarakat betapa dekatnya manusia dengan binatang, dan manusia lain akan diperlakukan secara yang sama apabila mereka keluar dari batas-batas yang dipandang waras oleh masyarakat. Dalam keseluruhan penanganan atas penyimpangan-penyimpangan ini, psikiater atau aparat sebenarnya tidak berperan sebagai ilmuwan, tetapi sebagai kekuasaan yang mengadili.

Foucault membayangkan menara pengawas dalam panoptisme selain dioperasikan oleh petugas, dapat dipergunakan oleh banyak individu dengan pelbagai kepentingan. Ia dapat menjadi tempat seorang filsuf yang haus pengetahuan akan manusia menjadi museum manusia. Ia bahkan menjadi tempat bagi mereka yang 
tergolong mempunyai sedikit penyimpangan seksual memperoleh kenikmatan dengan mengintip orang-orang. Dalam panoptisme inilah Foucault memperlihatkan adanya kekuasaan yang teselubung dalam pelbagai institusi dan lembaga.

Dari pemikiran Foucault di atas dapat dilihat bahwa kekuasaan di Indonesia bukanlan semata mata milik pemerintah yang berkuasa. Kekuasaan ada di mana-mana, karena kekuasaan merupakan satu dimensi dari relasi. Munculnya fenomena Organisasi Kemasyarakatan (Ormas) merupakan bagian dari relasi kekuasaan. Ormas dengan massa yang banyak akan lebih mudah mendapatkan legitimasi sosial apalagi setelah Ormas tersebut mendapatkan legitimasi hukum berupa pengakuan tentang keberadaannya. Pimpinan Ormas akan menjadi penguasa dan seolah berkuasa hingga mampu menandingi eksistensi pengusasa negara (pemerintah). Sering kali pimpinan Ormas memiliki ideologi berbeda dengan ideologi negara yang menaunginya. Pemaksaan ideologi Ormas untuk diterapkan pada ideologi negara bahkan ingin mengganti ideologi negara, sering kali menimbulkan prahara perpecahan bangsa. Fenomena ini akan dibahas lebih lanjut pada Bab III penelitian ini.

\subsection{Teori Sosiologi Hukum}

Dari sudut sejarah, sosiologi hukum untuk pertama kalinya diperkenalkan oleh seorang Itali yang bernama Anzilotti pata tahun 1882. Sosiologi hukum pada hakekatnya lahir dari hasil-hali pemikiran para ahli, baik di bidang filsafat hukum, ilmu maupun sosiologi. Hasil-hasil pemikiran tersebut tidak saja berasal dari individu-individu tetapi mungkinh juga besaral dari aliran-aliran yang mewakili sekelompok ahli pemikir, yang secara garis besar mempunyai pendapat yang berbeda.

Secara etimologis, sosiologi berasal dari kata latin, socius yang berarti kawan dan kata Yunani logos yang berarti kata atau berbicara. Jadi sosiologi adalah berbicara mengenai masyarakat.

Sosiologi hukum saat ini sedang berkembang pesat. Ilmu ini diarahkan untuk menjelaskan hukum positif yang berlaku (artinya isi dan bentuknya yang berubah-rubah menurut waktu dan tempat), dengan bantuan faktor-faktor kemasyarakatan. Tetapi disatu sisi hukum itu sendiri dijelaskan dengan bantuan hukum. Dalam dua hal itu, hukum dan dinamika kemasyarakatan diletakkan pada suatu tataran yang sama.

Pemikiran sosiologi hukum lebih berfokus pada keberlakuan empiris atau faktual dari hukum. Hal ini, memperlihatkan bahwa sosiologi hukum tidak secara langsung diarahkan pada hukum sebagai sistem konseptual, melainkan pada kenyataan sistem kemasyarakatan yang idalamnya hukum hadir sebagai pemeran utama. Objek tingkatan kedua adalah kaidah-kaidah hukum.

Hal tersebut di atas berbeda engan ilmu hukum normatif, memandang hukum dalam hukum itu sendiri (apa yang tertuang dalam peraturan). Eksponen dari aliran positifisme John Austin, mengatakan bahwa studi tentang filsafat hukum seharusnya merupakan studi tentang hukum yang benar-benar terdapat dalam sistem hukum, dan bukan hukum yang seharusnya ada dalam norma-norma moral (Achmad Ali, Sosiologi Hukum, hal 9).

Berbeda dengan hal tersebut, sosiologi hukum memandang hukum dari luar ukum. Dalam hal ini, sosiologi hukum mencoba untuk memperlakukan sistem hukum dari sudut pandang ilmu sosial. Pada adasarnya, sosiologi hukum berpendapat bahwa hukum hanyalah salah satu dari banyak sistem sosial dan bahwa justru sistem-sistem sosial lain, yang terdapat di dalam masyarakat, memberi arti dan pengaruh terhadap hukum.

Seorang ahli filsafat berkebangsaan Perancis bernama Aguste Cumte pada abad ke-19, menulis beberapa buah buku untuk mempelajari masyarakat. Dia berpendapat bahwa ilmu sosial mempunyai urutan tertentu berdasarkan logika metoda ilmiah dan bahwa setiap penelitian dilakukan melalui tahap-tahap tertentu untuk mencapai tahap akhir. Dia beranggapan bahwa saatnya telah tiba bagi kesahihan ilmiah terhadap penelitian kemasyarakatan. Sejak saat itu Comte memperkenalkan sosiologi sosial sebagai ilmu pengetahuan kemasyarakatan. Bagi Comte, sosiologi merupakan ilmu pengetahuan kemasyarakatan umum, yang merupakan hasil akhir dari perkembangan ilmu pengetahuan. Oleh karena itu, sosiologi didasarkan pada kemajuan yang telah dicapai oleh ilmu pengetahuan sebelumnya. Selain itu Comte mengatakan 
bahwa sosiologi harus dibentuk berdasarkan pengamatan dan tidak pada spekulasi keadaan masyarakat (Comte dalam Pengantar Sosiologi Hukum, 1--2).

Dari uraian di atas dapat dikatakan bahwa segala peristiwa yang terjadi di Indonesia erat kaitannya dengan masyarakat Indonesia. Demikian pula dasar-dasar berpikir dari Comte melalui teori Sosiologi Hukum merupakan panduan bagi penulis dalam melakukan penelitian ini. Di sisi lain, pendidikan hukum saat ini cenderung berorientasi kepada kuhum yang tertulis, yang selalu mementingkan aturan dan keteraturan. Keteraturan hukum merupakan sebuah keharusan guna mewujudkan rasa percaya terhadap hukum dan kepastian terhadap hukum. Hal ini sangat jelas tertulis dalam sistim ketatanegaraan di Negara Republik Indonesia dimana Pancasiila dan Undang Undang Dasar 1945 merupakan sumber dari segala sumber hukum. Segala aturan dan perundang-undangan yang ada maupun yang akan dibuat tidak boleh bertentangan dengan Pancasila dan Undang-Undang Dasar 1945. Dibawahnya terdapat 7 lembaga negara yang kedudukannya sejajar yaitu MPR, DPD, DPR, Presiden, MK, MA dan BPK. Ketujuh lembaga negara tersebut dibentuk berdasarkan Undang-Undang Dasar 1945.

Sesuai dengan amanat Undang-Undang Dasar 1945 disebutkan bahwa DPR bersama Presiden dapat membentuk Undang Undang. Salah satu Undang-Undang yang dihasilkan adalah Undang Undang Nomor 17 tahun 2013 tentang Orgasisasi Kemasyarakatan. Undang-Undang ini ternyata tidak mampu untuk mengatasi masalah pembubaran Organisasi Kemasyarakatan (Ormas) secara komprehensif (menyeluruh) karena hanya berupa pencabutan status badan hukum yang tertuang pada pasal 69 ayat 1 yang diartikan sebagai pembubaran Ormas seperti yang tertuang pada pasal 68 ayat 2 .

\section{Pembahasan}

\subsection{Tinjauan Politik}

Organisasi kemasyarakatan yang terbentuk di Indonesia memiliki tujuan yang berbeda-beda sesuai dengan keinginan kelompok yang membentuknya. Mulai dari organisasi kebudayaan, organisasi pendidikan, organisasi provesi tertentu dan ada pula organisasi untuk sekedar ber- kumpul tanpa tujuan yang jelas. Dari sekian banyak organisasi dengan tujuan yang berbeda tersebut, terdapat pula organisasi yang dibentuk untuk tujuan meraih kekuasaan. Mereka biasanya melakukan uji publik dengan mengumpulkan masa sebanyak-banyaknya. Mereka mengambil isu-isu yang hangat pada saat itu dan mengolah isu tersebut guna mendapatkan dukungan publik yang luas.

Di balik pendirian organisasi kemasyarakatan semacam itu, terdapat keinginan kuat dari kelompok pendiri untuk muncul sebagai penguasa informal yang dapat disepadankan dengan penguasa formal baik di tingkat lokal maupun di tingkat nasional. Mereka selalu membuat gerakan untuk mendapatkan legitimasi walaupun sebatas legitimasi informal. Namun gerakan yang mereka lakukan seolah-olah mendapatkan legitimasi formal. Masyarakat kelas tertentu sangat mudah untuk dihasut dengan menggunakan gerakan masa yang besar dan sebagian dari mereka beranggapan bahwa masa yang besar dianggap sudah dapat dijadikan sebagai legitimasi formal.

Hubungan antara kelompok pendiri organisasi kemasyarakatan dan pengikut organisasi kemasyarakatan merupakan hubungan yang saling membutuhkan. Para pendiri organisasi kemasyarakatan beranggapan bahwa organisasi yang mereka dirikan merupakan kehendak rakyat dan pantas untuk ikut mengelola dan menjalankan pemerintahan. Setidaknya kepentingan pendiri organisasi kemasyarakatan tersebut diperhitungkan sebagai kekuatan yang memaksa penguasa formal untuk menjalankan agendanya. Dibagian lain terdapat kelompok masa sebagai pengikut organisasi kemasyarakatan tersebut yang merasa kepentingannya disalurkan dan mereka seolah mendapatkan legitimasi untuk mendukung agenda organisasi kemasyarakatan yang didukungnya. Kepentingan pimpinan organisasi kemasyarakatan dan masa pendukung organisasi kemasyarakatan semacam ini sering kali terjadi hubungan relasi yang saling menguntungkan. Pimpinan organisasi kemasyarakatan selalu beranggapan bahwa kekuasaan merupakan setrategi yang harus diraih, karena melalui kekuasaan mereka dapat menggerakkan sistem, aturan, susunan dan regulasi.

Kejadian di atas sejalan dengan pendapat Michel Foucault, salah seorang 
filsuf pelopor strukturalisme juga berbicara tentang kekuasaan. Konsep Kekusasan Foucault dipengaruhi oleh Nietzsche. Foucault yang menilai bahwa filsafat politik tradisional selalu berorientasi pada soal legitimasi. Kekuasaan adalah sesuatu yang dilegitimasikan secara metafisis kepada negara yang memungkinkan negara dapat mewajibkan semua orang untuk mematuhinya. Kekuasaan bukanlah sesuatu yang hanya dikuasai oleh negara, sesuatu yang dapat diukur. Kekuasaan ada di mana-mana, karena kekuasaan adalah satu dimensi dari relasi. Di mana ada relasi, di sana ada kekuasaan.

Terdapatnya organisasi kemasyarakatan radikal yang sering melakukan kegiatan anarkis di Indonesia telah membuat pemerintah Indonesia yang memiliki legitimasi formal sebagai penguasa negara berdasarkan Undang undang Dasar 1945 harus melakukan pengendalian berupa pembatasan-pembatasan. Pembatasan dilakukan mulai dari pengendalian ijin kegiatan, tempat kegiatan bahkan sampai pengendalian perijinan pendirian organisasi. Pembatasan yang sudah dilakukan, sering kali tidak efektif untuk mengendalikan organisasi kemasyarakatan karena tidak diimbangi oleh tindakan tegas berupa pembubaran.

Mereka selalu berlindung di bawah Undang Undang Dasar 1945 pasal 28E ayat 3 yang berbunyi setiap orang berhak atas kebebasan berserikat, berkumpul dan mengeluarkan pendapat. Klausul dalam Undang Undang Dasar 1945 inilah yang menyulitkan pemerintah dalam membubarkan organisasi kemasyarakatan yang berbahaya bagi bangsa dan negara. Sering kali pembubaran organisasi kemasyarakatan tidak diikuti oleh sangsi individu pendukung organisasi kemasyarakatan tersebut. Karena kekuatan ideologi organisasi kemasyarakatan akan menjadi bahaya laten dan dapat menggerakkan anggotanya walaupun menggunakan organisasi tanpa bentuk. Organisasi tanpa bentuk ini akan lebih berbahaya daripada organisasi yang sudah jelas wujudnya.

\subsection{Tinjauan Hukum}

Pembubaran ormasi di Indonesia bukan merupakan perkara mudah karena selain adanya banyak kepentingan yang bermain di dalamnnya, terdapat pula tumpang tindih aturan. Di satu sisi Undang-Undang Dasar 1945 menyebutkan bahwa setiap orang berhak atas kebebasan berserikat, berkumpul dan mengeluarkan pendapat. Sedangkan di pihak lain, undang-undang menyebutkan bahwa pemerintah diijinkan untuk member sangsi berupa pembubaran ormas yang berbahaya bagi kehidupan bernangsa dan bernegara. Melihat aturan yang berlaku, penulis berusaha untuk membedah kedua aturan tersebut dan bila dikaitkan terhadap tata urutan perudang-undangan yang berlaku di Indonesia saat ini.

Dalam Undang-Undang Republik Indonesia Nomor 17 Tahun 2013 tentang Organisasi Kemasyarakatan pada Bab XVII disebutkan tentang sangsi bagi ormas yang melanggar aturan berorganisasi di wilayah Negara Kesatuan Republik Indonesia. Pasal tentang sangsi organisasi dimuat pada pasal 60 sampai dengan pasal 82 .

Dari gambaran tentang peraturan di atas terlihat bahwa organisasi kemasyarakatan yang sudah terbentuk dilindungi oleh undang-undang dan pelaksanaan kegiatan organisasi kemasyarakatan diatur lebih terinci dalam undang-undang. Permasalahan terjadi ketika dalam pelaksanaan kegiatan ormas tersebut tidak sesuai bahkan bertentangan dengan undang- undang. Sementara Undang-Undang Dasar 1945 mengamanatkan bahwa setiap warga negara bebas untuk berserikat, berkumpul dan mengeluarkan pendapat.

Organisasi kemasyarakatan yang sudah terlanjur terbentuk dan sudah besar dan mengakar di masyarakat tentu sangat rentan terjadi gejolak di masyarakat bahkan dapat mempengaruhi suasana bernegara di Indonesia. Legitimasi sosial yang sudah terbangun dari ormas tersebut tidak mudah untuk dihilangkan. Legitimasi yang kuat pada ormas dan pimpinan ormas seolah sudah memberikan kekuasaan kepada mereka untuk berbuat sesuai dengan ideologi yang mereka kembangkan. Legitimasi ormas yang kuat walaupun hanya pada dapat tataran informal, menjadi saingan penguasa atau pemerintah yang memiliki legitimasi formal yang diatur dalam Undang-Undang Dasar 1945. Benturan kepentingan antara negara dan ormas yang seolah berkuasa akan menjadi permasalahan hukum bila tidak ditangani dengan baik.

Seperti yang diungkapkan oleh Foucault yang menyatakan bahwa filsafat 
politik tradisional selalu berorientasi pada soal legitimasi. Terlihat jelas bahwa ormas yang dinilai mengganggu kedaulatan negara selalu berusaha untuk mendapatkan legitimasi kekuasaan dari anggotanya walaupun dalam tataran informal. Legitimasi tersebut terus diperjuangkan untuk dapat meraih kekuasaan. Dengan kekuasaan ormas tersebut dapat mewajibkan semua orang untuk mematuhi segala sesuatu yang harus dilakukan sesuai dengan ideologinya.

Foucault juga mengatakan bahwa kekuasaan adalah sesuatu yang dilegitimasikan secara metafisis kepada negara yang memungkinkan negara dapat mewajibkan semua orang untuk mematuhinya. Namun menurut Foucault, kekuasaan adalah satu dimensi dari relasi. Di mana ada relasi, di sana ada kekuasaan.

Dalam pandangan Foucault tersebut sangat jelas bahwa untuk menjalankan seluruh agenda ormas sesuai dengan ideologi ormas yang telah dikembangkan, diperlukan legitimasi untuk meraih kekuasaan. Untuk mendapatkan kekuasaan maka ormas harus memperkuat relasi dengan pendukungnya dan memperbanyak pendukung sebagai relasi. Memperkuat relasi akan dapat memperkuat kekuasaan.

\subsection{Solusi Pembubaran Ormas}

Dalam uraian di atas dapat dimengerti bahwa telah terjadi ketidaksingkrunan dalam pemberian sangsi kepada organisasi kemasyarakatan yang sudah terbentuk melalui aturan perundang-undangan. Melalui undang-undang sebuah organisasi kemasyarakatan dibentuk dengan segala aturan yang sudah ditentukan. Bila organisasi kemasyarakatan tersebut ternyata tidak melaksanakan ketentuan perundang-undangan, maka ormas tersebut sangat sulit untuk dibubarkan. Hal ini terjadi karena adanya peraturan yang lebih tinggi yaitu Undang- Undang Dasar 1945 terutama pasal $28 \mathrm{E}$ ayat 3 yang berbunyi setiap orang berhak atas kebebasan berserikat, berkumpul dan mengeluarkan pendapat. Apalagi dalam Undang-Undang Nomor 10 Tahun 2014 tentang Tata Urutan Perundangan-Undangan Republik Indonesia pasal 7 diatur sebagai berikut :

1. Undang-undang Dasar 1945

2. Undang-Undang/Peraturan Pemerintah Pengganti Undang-undang
3. Peraturan Pemerintah

4. Peraturan Presiden

5. Peraturan Daerah, yang meliputi:

- Peraturan Daerah Provinsi

- Peraturan Daerah Kabupaten/Kota

- Peraturan Desa.

Sangat jelas bahwa Undang-Undang tentang Organisasi Kemasyarakatan dalam tata urutan perundang-undangan letaknya dibawah Undang Undang Dasar 1945.

Dalam sengketa hukum tersebut penulis mencoba untuk menawarkan solusi berupa Amandemen Undang- Undang Dasar 1945. Dalam Amandemen tersebut dimuat kriteria dari organisasi kemasyarakatan yang berbahaya bagi keselamatan berbangsa, bernegara dan Pancasila. Solusi lain adalah memperluas kewenangan Mahkamah Konstitusi yang sebelumnya berwenang membubarkan partai politik selain kewenangan lainnya, menjadi memiliki kewenangan tambahan berupa pembubaran ormas.

Alasannya adalah bahwa ormas yang menyimpang dari ideologi negara dan membahayakan kehidupan berbangsa dan bernegara sama berbahayanya terhadap partai politik yang memiliki ideologi bukan Pancasila dan melakukan gerakan yang membahayakan kehidupan berbangsa dan bernegara.

Dengan memberikan kewenangan yang lebih kepada Mahkamah Konstitusi berupa kewenangan untuk membubarkan ormas maka pembubaran ormas tersebut dilindungi oleh Undang Undang Dasar 1945. Jadi pembubaran ormas dengan dengan kriteria yang sangat jelas yaitu membahayakan kehidupan berbangsa dan bernegara, tidak dapat dipertentangkan lagi dengan Undang-Undang Dasar 1945 pasal $28 \mathrm{E}$ ayat 3 yang berbunyi setiap orang berhak atas kebebasan berserikat, berkumpul dan mengeluarkan pendapat.

Permasalahan yang akan timbul berikutnya adalah apakah anggota Majelis Permusyawaratan Rakyat yang anggotanya terdiri dari anggota Dewan Perwakilan Rakyat dan Dewan Perwakilan Daerah mau dan setuju dengan amandemen tersebut ? ; Pertanyaan tersebut adalah pertanyaan yang sangat wajar ditengah skeptifisme masyarakat terterhadap anggota parlemennya. Namun rakyat masih menyimpan harapan, bahwa anggota parlemen di Majelis Permusyawaraatan Rakyat akan 
melihat kepentingan bangsa dan negaranya diatas kepentingan kelompok, golongan dan partainya. Keselamatan bangsa dan negara adalah harga mati.

\subsection{Contoh Kasus}

Sebuah contoh kasus yang terjadi di Indonesia adalah organisasi kemasyarakatan yang bernama HTI (Hizbut Tahrir Indonesia) dinyatakan dibubarkan oleh pemerintah Indonesia melalui konfrensi pers yang dilaksanakan pada tanggal $12 \mathrm{Mei}$ 2017. Dalam konfrensi pers tersebut, Menteri Koordinator Bidang Politik, Hukum dan Keamanan Wiranto menyatakan bahwa pembubarkan Hizbut Tahrir Indonesia (HTI) bukan tanpa alasan. Pembubaran didasari oleh ideologi khilafah yang didakwahkan kepada HTI, mengancam kedaulatan politik negara yang berbentuk NKRI (Negara Kesatuan Republik Indonesia). Ideologi khilafah yang disuarakan HTI, menurut Wiranto, bersifat transnasional. Artinya, ideologi ini meniadakan konsep nation state. "Untuk mendirikan negara Islam dalam konteks luas sehingga negara dan bangsa jadi absurd, termasuk Indonesia yang berbasis Pancasila dan UUD 1945."

Wiranto mengatakan bahwa keberadaan HTI dirasa semakin meresahkan. Pasalnya dari laporan kepolisian banyak penolakan di berbagai daerah, bahkan memicu konflik horizontal antara masyarakat yang pro dan kontra. "Kalau dibiarkan akan meluas lagi,". Wiranto menganggap tidak akan ada kompromi terhadap organisasi manapun yang mengancam eksistensi Indonesia, termasuk HTI.'Kewajiban kita yang lahir di Indonesia mempertahankan warisan ini, warisan keberadaan NKRI".

Pernyataan pembubaran ormas HTI dilakukan pemerintah melalui mekanisme hukum sesuai dengan Undang Undang Republik Indonesia Nomor 17 Tahun 2013 tentang Organisasi Kemasyarakatan pasal 70. Dalam pasal itu disebutkan bahwa Permohonan pembubaran Ormas berbadan hukum diajukan ke pengadilan negeri oleh kejaksaan hanya atas permintaan tertulis dari menteri yang menyelenggarakan urusan pemerintahan di bidang hukum dan hak asasi manusia.

Dalam Undang-Undang Nomor 10 Tahun 2014 tentang Tata Urutan Perundan-
gan-Undangan Republik Indonesia pasal 7 diatur sebagai berikut :

1. Undang-undang Dasar 1945

2. Undang-Undang/Peraturan Pemerintah Pengganti Undang-undang

3. Peraturan Pemerintah

4. Peraturan Presiden

5. Peraturan Daerah, yang meliputi:

- Peraturan Daerah Provinsi

- Peraturan Daerah Kabupaten/Kota

- Peraturan Desa

Tata urutan perudang-undangan seperti tersebut di atas sangat jelas diatur bahwa Undang-Undang tingkatannya berada di bawah Undang-Undang Dasar 1945. Pembubaran ormas dengan bersandar pada pasal 68 Undang-Undang Ormas berupa menjatuhkan sangsi pencabutan status badan hukum sangat bertentangan dengan Undang-Undang Dasar 1945 pasal 28E ayat 3 yang berbunyi setiap orang berhak atas kebebasan berserikat, berkumpul dan mengeluarkan pendapat.

Kalaupun pembubaran ormas tersebut tetap dipaksakan maka ideologi ormas yang sudah tertanam pada pimpinan dan pendukung ormas tersebut akan tetap terpelihara dan mereka akan tetap melakukan gerakan dengan menggunakan nama organisasi yang berbeda. Bahkan tidak tertutup kemungkinan mereka menggunakan jalur organisasi tanpa bentuk (OTB) atau gerakan bawah tanah sehingga sangat sulit untuk dibubarkan. Organisasi tanpa bentuk tidak dapat dibubarkan karena mereka tidak pernah terdaftar sebagai organisasi resmi tapi gerakan mereka yang didorong oleh ideologi yang meraka yakini akan sangat terasa mengganggu kehidupan berbangsa dan bernegara.

Melihat kenyataan yang seperti tersebut di atas maka pada hari Rabu, tanggal 12 Juli 2017 pemerintah melalui Menteri Koordinator bidang Hukum dan Hak Asasi Manusia, Jenderal TNI (Purn) Dr. H. Wiranto, S.H, menerbitkan sebuah Peraturan Pemerintah Pengganti Undang-Undang Republik Indonesia (Perpu) Nomor 2 Tahun 2017 Tentang Perubahan Atas Undang-Undang Nomor 17 Tahun 2013 Tentang Organisasi Kemasyarakatan.

Dalam konsfrensi pers resmi yang disampaikan pemerintah disebutkan bahwa sampai saat ini sudah terdaftar 344.039 organisasi kemasyarakatan (ormas) baik di tingkatan pusat maupun daerah di In- 
donesia. Demikian banyaknya ormas yang terdapat di Indonesia seharusnya dapat menjadi bagian dari pembangunan bangsa dan negara di tingkatannya masing masing. Namun kenyataannya tidak semua ormas tersebut melakukan kegiatan sesuai dengan aturan sebagaimana yang disampaikan pada saat pendaftaran. Diakui oleh pemerintah bahwa terdapat kekosongan hukum dalam mengatasi ormas semacam ini, dimana tidak ada satu pun aturan yang secara tegas memberikan wewenang kepada pemerintah untuk membubarkan ormas yang berbahawa bagi keutuhan NKRI. (Isi perpu terlampir).

Kesadaran pemerintah tersebut sudah sesuai dengan analisa yang disampaikan penulis pada penelitian ini. Namun penerbitan perpu oleh pemerintah bukanlah tanpa kelemahan. Kelemahan nyata seperti yang sudah penulis sampaikan di atas adalah adanya kenyataan bahwa Undang-Undang Dasar 1945 terutama pasal 28E ayat 3, memberikan jaminan bahwa setiap warga negara Republik Indonesia berhak atas kebebasan berserikat, berkumpul dan mengeluarkan pendapat.

Namun Perppu nomor 2 tahun 2017 lebih merujuk pada UUD 1945 Pasal 28J yang berbunyi:

(1) Setiap orang wajib menghormati hak asasi manusia orang lain dalam tertib kehidupan bermasyarakat, berbangsa, dan bernegara.

(2) Dalam menjalankan hak dan kebebasannya, setiap orang wajib tunduk kepada pembatasan yang ditetapkan dengan undang-undang dengan maksud semata-mata untuk menjamin pengakuaan serta penghormatan atas hak dan kebebasan orang lain dan untuk memenuhi ketentuan yang adil sesuai dengan pertimbangan moral, nilai-nilai ogama, keamanan dan ketertiban umum dalam suatu masyarakat demokratis.

Penulis berpendapat bahwa Pasal 28J UUD 1945 merupakan sebuah penegasan tentang pembatasan-pembatasan yang ditetapkan dengan undang-undang. Tetapi tidak meniadakan maksud dari Pasal 28E ayat 3 Undang-Undang Dasar 1945 yang memberikan jaminan bahwa setiap warga negara Republik Indonesia berhak atas ke- bebasan berserikat, berkumpul dan mengeluarkan pendapat.

Kelemahan tersebut ditambah pula oleh adanya Undang-Undang Nomor 10 Tahun 2014 tentang Tata Urutan Perundangan-Undangan Republik Indonesia terutama pada pasal 7 yang menjelaskan bahwa Undang-Undang dan Perpu kedudukannya berada di bawah Undang-Undang dasar 1945.

Kenyataan seperti tersebut di atas menyebabkan kedudukan Perpu yang sudah diterbitkan pun sangat lemah dalam rangka pembubaran ormas. Hal tersebut disebabkan karena pembubaran tersebut hanya pada tataran pencabutan badan hukum ormas dan bukan pada pembubaran organisasi yang sebenarnya. Walaupun badan hukum ormas tersebut dibubarkan namun secara organisasi ormas tersebut akan terus ada walaupun mereka harus beroganisasi tanpa bentuk (OTB).

Ideologi ormas radikal yang membahayakan kehidupan berbangsa dan bernegara adalah meraih kekuasaan. Seperti dikemukakan oleh Foucault yang mengatakan bahwa kekuasaan ada di mana-mana, karena kekuasaan adalah satu dimensi dari relasi. Di mana ada relasi, di sana ada kekuasaan. Dari analisa tersebut di atas, dapat diyakini bahwa sepanjang anggota ormas tersebut dapat berkumpul walaupun tanpa nama organisasi, mereka tetap berbahaya bagi kelangsungan kehidupan berbangsa dan bernegara.

Jadi, walaupun pemerintah menerbitkan Perpu, namun tidak sepenuhnya dapat membubarkan organisasi radikal yang berbahaya bagi kelangsungan kehidupan berbangsa dan bernegara sampai ke akar akarnya. Jalan terbaik adalah seperti yang telah disampaikan penulis $d$ atas yaitu memberikan tambahan kewenangan kepada Mahkamah Konstitusi untuk dapat membubarkan Organisasi Kemasyarakatan (Ormas) melalui Amandemen Undang-Undang Dasar 1945.

\section{PENUTUP \\ 4.1 Simpulan}

Berdasarkan uraian diatas, dapat disimpulan antara lain:

1. Dibalik pendirian ormas yang membahayakan kehidupan berbangsa dan bernegara di Indonesia, terdapat keinginan kuat dari kelompok pendiri ormas terse- 
but untuk muncul sebagai penguasa informal yang dapat disepadankan dengan penguasa formal, baik di tingkat lokal maupun nasional dengan membuat gerakan untuk memdapatkan legitiasi rakyat maupun pengikutnya. Kepentingan pimpinan ormas dan masa pendukungnya sering kali terjadi hubungan relasi yang saling menguntungkan. Pimpinan ormas semacam ini selalu beranggapan bahwa kekuasaan merupakan setrategi yang harus diraih, karena melalui kekuasaan mereka dapat menggerakkan sistem, aturan, susunan dan regulasi.

2. Organisasi kemasyarakatan (ormas) yang telah berdiri di Indonesia, dalam implementasi kegiatannya tidak semua mengikuti aturan yang berlaku di Indonesia. Sebagian dari mereka memiliki agenda lain dan ideologi lain yang terbukti dari gerakannya di masyarakat yang menyimpang dari ideologi Pancasila dan membahayakan kehidupan berbangsa dan bernegara. Ormas semacam ini sangat sulit dibubarkan karena adanya aturan yang tumpang tindih antara Undang Undang Dasar 1945 khususnya pasal $28 \mathrm{E}$ ayat 3 yang berbunyi setiap orang berhak atas kebebasan berserikat, berkumpul dan mengeluarkan pendapat serta adanya undang undang khususnya Nomor 17 Tahun 2013 tentang Organisasi Kemasyarakatan khususnya pada Bab XVII disebutkan tentang sangsi bagi ormas yang melanggar aturan berorganisasi di wilayah Negara Kesatuan Republik Indonesia.

3. Undang-Undang Nomor 17 Tahun 2013 selanjutnya dirubah melalui terbitnya Peraturan Pemerintah Pengganti Undang-Undang (Perpu) Nomor 2 Tahun 2017. Walaupun demikian, Perpu tersebut tetap memiliki kelemahan karena hanya merujuk pada UUD 1945 Pasal 28J ayat 2 yang mengatakan bahwa setiap orang wajib tunduk kepada pembatasan yang ditetapkan dengan undang-undang. Tetapi pasal tersebut tidak meniadakan maksud dari Pasal 28E ayat 3 UUD 1945 yang memberikan jaminan bahwa setiap warga negara Republik Indonesia berhak atas kebebasan berserikat, berkumpul dan mengeluarkan pendapat.

4. Kelemahan tersebut ditambah pula oleh adanya Undang Undang Nomor $10 \mathrm{Ta}-$ hun 2014 tentang Tata Urutan Perundangan-Undangan Republik Indonesia terutama pada pasal 7 yang menjelaskan bahwa Undang Undang dan Perpu kedudukannya berada di bawah Undang Undang dasar 1945.

5. Solusi yang ditawarkan penulis dalam mengatasi ormas yang berbahaya dalam kehidupan berbangsa dan bernegara khususnya dalam hal pembubaran ormas adalah dengan melakukan amandemen terhadap Undang Undang Dasar 1945. Amandemen ini dilakukan dengan memberikan kewenangan yang lebih luas kepada Mahkamah Konstitusi, dimana Mahkamah Konstitusi tidak saja dibolehkan untuk membubarkan partai politik tetapi diberikan ruang untuk membubarkan ormas.

6. Sebuah contoh kasus yang terjadi di Indonesia adalah ketika organisasi kemasyarakatan yang bernama HTI (Hizbut Tahrir Indonesia) dinyatakan dibubarkan oleh pemerintah Indonesia melalui konfrensi pers yang dilaksanakan pada tanggal 12 Mei 2017. Pembubaran didasari oleh ideologi khilafah yang didakwahkan HTI, mengancam kedaulatan politik negara yang berbentuk NKRI (Negara Kesatuan Republik Indonesia). Pernyataan pembubaran ormas HTI dilakukan pemerintah melalui mekanisme hukum sesuai dengan Undang Undang Republik Indonesia Nomor 17 Tahun 2013 tentang Organisasi Kemasyarakatan khususnya pasal 70. Sedangkan Undang Undang Dasar 1945 pasal $28 \mathrm{E}$ ayat 3 menyatakan bahwa setiap orang berhak atas kebebasan berserikat, berkumpul dan mengeluarkan pendapat. Dalam Undang Undang Nomor 10 Tahun 2014 tentang Tata Urutan Perundangan-Undangan Republik Indonesia pasal 7 diatur bahwa UU dalam tata urutan perundang undang berada di bawah UUD 1945. Jadi HTI secara badan hukum memang dapat dibubarkan organisasinya, tetapi gerakan mereka dalam organisasi tanpa bentuk (OTB) akan terus berjalan sesuai dengan dorongan ideologi yang mereka pahami.

\subsection{Saran-saran}

Dalam siatuasi dan kondisi kehidupan berbangsa dan bernegara di Republik Indonesia yang belum memiliki hukum yang 
kuat di bidang keorganisasian masyarakat, maka penulis menyarankan sebagai berikut :

1 Harus diupayakan untuk menciptakan situasi sosial politik yang kondusip sehingga permasalahan sosial dapat tertangani dengan baik. Kondisi yang baik akan meminimalkan niat masyarakat untuk bergabung dalam organisasi kemasyarakatan (ormas) radikal.

2 Mengingat kuarang kuatnya kedudukan Undang Undang Nomor 17 tahun 2013 tentang oerganisasi kemasyarakatan maka melalui Peraturan Pemerintah Pengganti Undang-Undang Republik Indonesia Nomor 2 Tahun 2017 Tentang Perubahan atas Undang-Undang Nomor 17 Tahun 2013 Tentang Organisasi Kemasyarakatan diharapkan pemerintah menunjukkan sikap yang tegas walaupun terdapat kemungkinan Perpu tersebut di anulir oleh Mahkamah Konstitusi (MK) karena bertentangan dengan Undang Undang Dasar 1945 khususnya pasal $28 \mathrm{E}$ ayat 3 .

3. Solusi terbaik dalam mengatasi tumpang tindihnya aturan hukum tentang Ormas di Indonesia adalah melalui Amandemen Undang-Undang Dasar 1945 dengan menambahkan kewenangan Mahkamah Konstitusi untuk dapat membubarkan organisasi kemasyarakatan yang dalam aktifitas organisasinya menyimpang dari Undang-Undang Dasar 1945 dan Pancasila

DAFTAR PUSTAKA

Al-Barry, Dahlan Yacum M. 2001. Kamus Sosiologi Antropologi. Surabaya: Indah.
Arikunto, Suharsimi. 2002. Prosedur Penelitian Sebuah Pendekatan Praktek. Jakarta: Rineka Cipta.

Beilharz, Peter. 2003. Teori-Teori Sosial: Observasi Kritis terhadap para Filosof Terkemuka. Yogyakarta: Pustaka Pelajar.

Campbell, Tom. 1994. Tujuh Teori Sosial. Sketsa, Penilaian, Perbandingan. Yogyakarta: Kanisius.

Departemen Pendidikan Nasional. 2005. Kamus Besar Bahasa Indonesia. Jakarta: Balai Pustaka.

Miles \& Huberman A. 1992. Analisis Data Kualitatif. Jakarta: Universitas Indonesia.

Mulyana, Deddy. 2001. Metodologi Penelitian Kualitatif Paradigma Baru Ilmu Komunikasi dan Ilmu Sosial Lainnya. Bandung: Remaja Rosdakarya.

Sanderson, Stephen K. 2003. Makrososiologi, Sebuah Pendekatan terhadap Realitas Sosial. Jakarta: PT Raja Grafindo Persada.

Tim Permata Press, 2011, UUD 1945 Amandemen I, II, III, \& IV, Permata Press.

Yesmil Anwar dan Adang. 2008. Pengantar Sosiologi Hukum. Grasindo, PT. Gramedia Widiasarana Indonesia. 